\title{
Dual Responsive Ratiometric Fluorescent Probe for Hypochlorite and Peroxynitrite Detection and Imaging in \\ Vitro and in Vivo
}

Tonghui Huang, ${ }^{*}{ }^{\dagger}$ Shirong Yan,,${ }^{\dagger}$ Yongbo Yu, ${ }^{\dagger}$ Yunsheng Xue,${ }^{\dagger}$ Yanyan $\mathrm{Yu},{ }^{\dagger}$ and

$$
\text { Cuiping } \operatorname{Han}^{*}, \ddagger \S
$$

${ }^{\dagger}$ School of Pharmacy, Xuzhou Medical University, Xuzhou, 221004, PR China; Email: tonghhuang@xzhmu.edu.cn

\$ School of Medical Imaging, Xuzhou Medical University, Jiangsu, Xuzhou 221004, China; Email: hancp@xzhmu.edu.cn

$\S$ Department of Radiology, Affiliated Hospital of Xuzhou Medical University, Xuzhou, 221004, China

\section{Table of Contents}

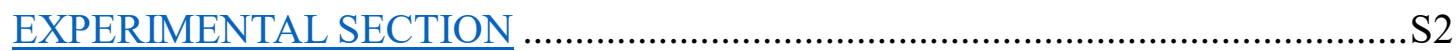

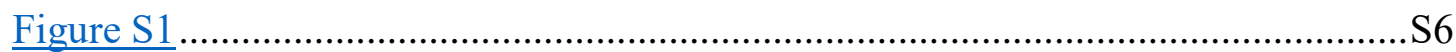

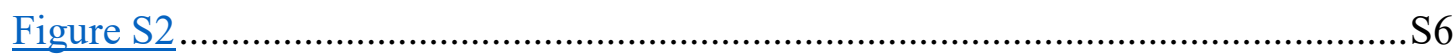

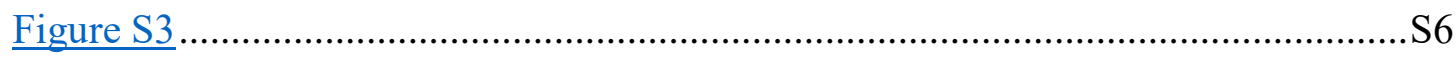

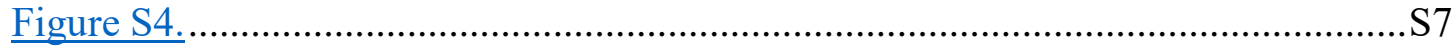

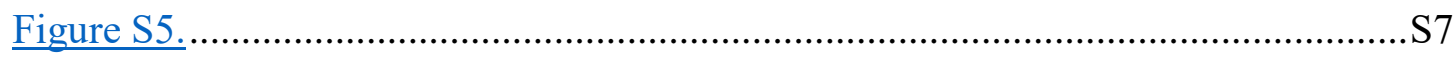

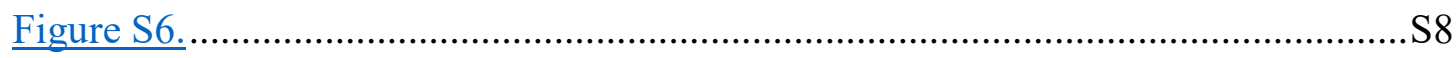

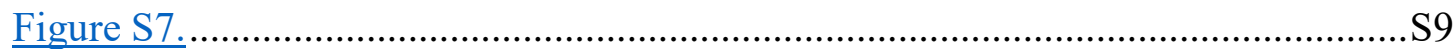

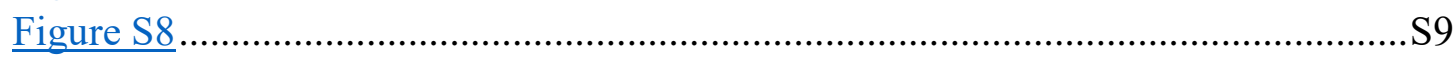

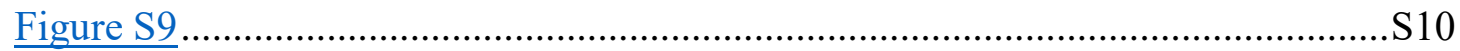

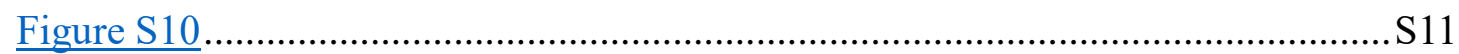

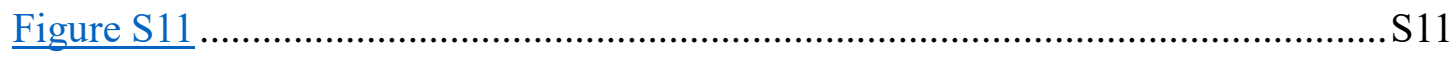

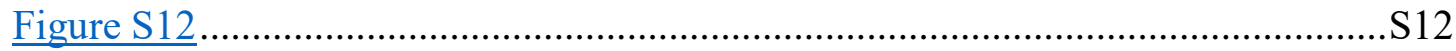

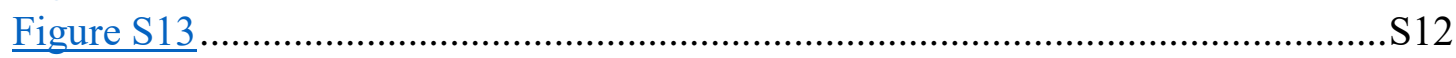

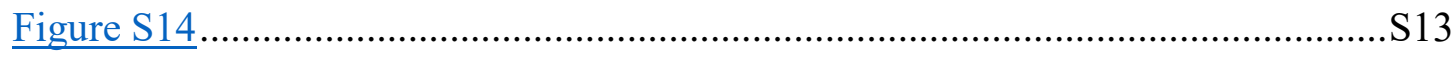

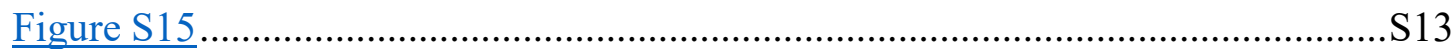

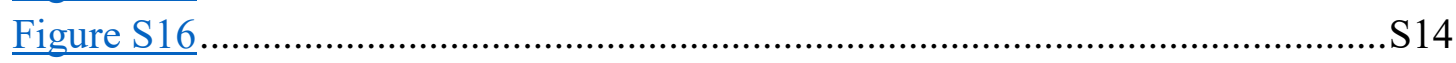

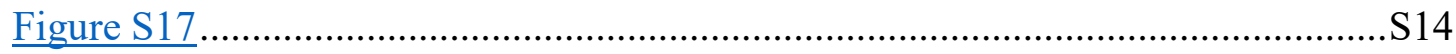

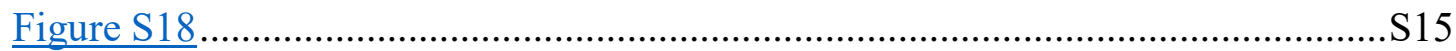




\section{EXPERIMENTAL SECTION}

\section{Materials and Instruments}

The organic solvents and chemical reagents were obtained from corresponding companies and utilized without any additional purification. All organic solvents were of analytical grade. $\mathrm{NaClO}$ served as the $\mathrm{ClO}^{-} / \mathrm{HClO}$ source. The bioimaging experiments were performed on a Leica system from Leica Microsystems, and LAS X (Leica Application Suite X) was the analysis software. The wavelengths of blue, green, and red channels were 420-480, 480-570, and 570-650 nm, respectively; the excitation wavelength was $405 \mathrm{~nm}$ for all channels. The JNM-ECZR FT-NMR spectrometer (400 $\mathrm{MHz}$ ) was utilized to record the NMR spectra; TMS and $\mathrm{CDCl}_{3}$ were utilized as the endogenous reference and solvent, respectively. The maXis ${ }^{\mathrm{TM}}$ 4G-UHR-TOF spectrograph (Bruker Daltonics) was used to record the mass spectra. The UV-6100 $\mathrm{UV} / \mathrm{Vis}$ spectrophotometer was employed for obtaining the UV-Vis spectra.

\section{Cell Culture and Cytotoxicity Assay}

The RAW 264.7 cells were cultivated in the DMEM containing $10 \%$ fetal bovine serum (FBS), $1 \%$ penicillin, and $1 \%$ streptomycin, and incubated at $37{ }^{\circ} \mathrm{C}$ and $5 \% \mathrm{CO}_{2}$ in a cell culture tank. For the cytotoxicity assay, the cells were seeded into the 96 -well plates and incubated in a constant-temperature incubator containing $5 \% \mathrm{CO}_{2}$ at $37{ }^{\circ} \mathrm{C}$. Further, the PTZ-H solution of different concentrations (1-100 $\mu \mathrm{M})$ was added to each well. The cells were incubated for $24 \mathrm{~h}$, and $0.5 \mathrm{mg} / \mathrm{mL}$ of MTT was added, followed by incubation for an additional $4 \mathrm{~h}$ in the cell culture tank. After discarding the MTT solution, $100.0 \mu \mathrm{L}$ of dimethyl sulfoxide (DMSO) were added, and the absorbance (OD) value was detected at $550 \mathrm{~nm}$ using a microplate reader (Varioskan LUX Reader, Thermo Fisher Scientific).

\section{Fluorescence imaging in animal tissue slice.}

Institute of Cancer Research (ICR) mice were chosen for the animal test. All animal studies were approved by the Ethics Committee and IACUC of Xuzhou Medical University and conducted in compliance with European guidelines for the care and use of laboratory animals. The ICR mice liver and hippocampal tissue were sectioned into 
many $3 \mu \mathrm{m}$ thickness layers. Tissue sections were deparaffinized in xylene before rehydration in graded alcohols and washed by PBST $5 \mathrm{~min} \times 2$. Divide the slices into five groups, (first group) The slices were incubated with the PTZ-H probe $(5.0 \mu \mathrm{M})$ for $20 \mathrm{~min}$. (second group) The slices were pretreated with $\mathrm{ClO}^{-}(50.0 \mu \mathrm{M}, 20 \mathrm{~min})$, and then incubated with PTZ-H probe $(5.0 \mu \mathrm{M}, 20 \mathrm{~min})$. (third group) The slices were pretreated with $\mathrm{ONOO}^{-}(50.0 \mu \mathrm{M}, 20 \mathrm{~min})$ and then incubated with PTZ-H probe (5.0 $\mu \mathrm{M}, 20 \mathrm{~min}$ ). (forth group) The slices were pretreated with $\mathrm{ClO}^{-}(50.0 \mu \mathrm{M})$ and $\mathrm{ONOO}^{-}$ $(50.0 \mu \mathrm{M})$ for a period of $30 \mathrm{~min}$, subsequently incubated with PTZ-H probe $(50.0 \mu \mathrm{M}$, $20 \mathrm{~min}$ ). Scale bar, $50 \mathrm{~mm}$. Finally, slices were mounted under coverslips by neutral gum.

\section{Fluorescence imaging in zebrafish.}

Zebrafish were provided by HuanTe biological corporation (Hangzhou, China). Zebrafish were incubated in $\mathrm{E} 3$ media $(15 \mathrm{mM} \mathrm{NaCl}, 0.5 \mathrm{mM} \mathrm{KCl}, 1 \mathrm{mM} \mathrm{MgSO} 4,1$ $\mathrm{mM} \mathrm{CaCl}_{2}, 0.15 \mathrm{mM} \mathrm{KH}_{2} \mathrm{PO}_{4}, 0.05 \mathrm{mM} \mathrm{Na}_{2} \mathrm{HPO}_{4}$ and $\left.0.7 \mathrm{mM} \mathrm{NaHCO} 3 ; \mathrm{pH} 7.5\right)$ containing $5 \mu \mathrm{M}$ PTZ-H probe at $28^{\circ} \mathrm{C}$ for $1 \mathrm{~h}$, and then, the residual probe was washed by the $\mathrm{E} 3$ media. To image the $\mathrm{ClO}^{-}$and $\mathrm{ONOO}^{-}$, zebrafish larvae (three-days) were put into a $50 \mathrm{~mm}$ Petri dish filled with E3 media containing BTSA for $1 \sim 5 \mathrm{~h}$. Fluorescence imaging was subsequently carried out by a confocal laser scanning microscope with an objective lens $(\times 10)$.

\section{Synthesis of Compound ONOO-N.}

Compound ONOO-N was synthesized according to the reported method ${ }^{[1]}$. Generally, isatoic anhydride (2.93 g, $15.27 \mathrm{mmol})$, 2-Aminothiophenol (2.55 mL, 20.37 $\mathrm{mmol})$, Sodium acetate $(1.2 \mathrm{~g}, 12.43 \mathrm{mmol})$ in $\mathrm{AcOH}(120 \mathrm{~mL})$ was refluxed for $1.5 \mathrm{~h}$ under Argon. The reaction was cooled to r.t., and the solution was quenched with solid $\mathrm{NaHCO}_{3}$ and added EtOAc $(100 \mathrm{~mL})$. The organic layer was washed with $\mathrm{H}_{2} \mathrm{O}(2$ x 50 $\mathrm{mL})$, brine $(50 \mathrm{~mL})$, dried $\left(\mathrm{MgSO}_{4}\right)$, and concentrated in vacuo to afford the crude material and used directly for the next step.

\section{Synthesis of Compound ONOO-OH.}


The compound $\mathbf{S 5}$ was prepared according to previously reported method ${ }^{[2]}$ and used directly for the next step reaction. Sodium borohydride $(0.23 \mathrm{~g}, 6 \mathrm{mmol})$ and acetic acid (0.36 g, $6 \mathrm{mmol})$ were added to a mixture of compound ONOO-N (1.18 g, $5.08 \mathrm{mmol})$ and 5 -hydroxyvaleraldehyde $(510 \mathrm{mg}, 5 \mathrm{mmol})$ in $10 \mathrm{~mL}$ of 1,2-dichloroethane. The mixture was stirred at room temperature and monitored by TLC (petroleum ether: ethyl acetate $=10: 1)$. The starting material was totally consumed artier $10 \mathrm{~h}$. Solid sodium bicarbonate was added to quench the reaction. The mixture was extracted with $30 \mathrm{~mL}$ of ethyl acetate and washed with $50 \mathrm{~mL}$ of water. The organic phase was dried over anhydrous sodium sulfate and concentrated under reduced pressure to obtain a crude product, which was purified by column chromatography (Petroleum ether: Ethyl acetate $=10: 1)$ to give a yellow oily product. ${ }^{1} \mathrm{H}$ NMR $\left(400 \mathrm{MHz}, \mathrm{CDCl}_{3}\right): \delta 8.98(\mathrm{~s}, 1 \mathrm{H}), 7.93$ $(\mathrm{d}, J=8 \mathrm{~Hz}, 1 \mathrm{H}), 7.85(\mathrm{~d}, J=8.0 \mathrm{~Hz}, 1 \mathrm{H}), 7.72(\mathrm{dd}, J=8.0 \mathrm{~Hz}, 1.2 \mathrm{~Hz}, 1 \mathrm{H}), 7.43$ (q, $J=14.8 \mathrm{~Hz}, 1 \mathrm{H}), 7.35-7.29$ (m, 2H), 6.77 (d, $J=8.0 \mathrm{~Hz}, 1 \mathrm{H}), 6.67$ (t, $J=14.8 \mathrm{~Hz}, 1 \mathrm{H})$, $3.70(\mathrm{t}, J=12.8 \mathrm{~Hz}, 2 \mathrm{H}), 3.33(\mathrm{t}, J=14 \mathrm{~Hz}, 2 \mathrm{H}), 1.85-1.69(\mathrm{~m}, 2 \mathrm{H}), 1.67-1.61(\mathrm{~m}, 4 \mathrm{H})$, 1.35 (s, $1 \mathrm{H}) .{ }^{13} \mathrm{C} \mathrm{NMR}\left(100 \mathrm{MHz}, \mathrm{CDCl}_{3}\right): \delta 169.6,153.6,147.6,133.2,132.2,130.8$,

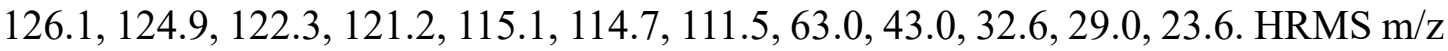
calcd for $\mathrm{C}_{18} \mathrm{H}_{20} \mathrm{~N}_{2} \mathrm{OS}[\mathrm{M}+\mathrm{Na}]^{+}$335.1194, found 335.1185.

\section{Synthesis of Compound ONOO-B.}

A mixture of compound ONOO-OH (100 mg, $0.33 \mathrm{mmol})$ and potassium carbonate (138 $\mathrm{mg}, 1 \mathrm{mmol}$ ) in $10 \mathrm{~mL}$ of anhydrous acetonitrile was added 4bromomethylphenylboronic acid pinacol ester (100 mg, $0.34 \mathrm{mmol})$. The mixture was stirred and heated at $60{ }^{\circ} \mathrm{C}$ and monitored by TLC (Petroleum ether: Ethyl acetate $=1$ : 1). Six hours later, the starting material was totally consumed as indicated by TLC. The reaction mixture was then cooled to room temperature, poured into $50 \mathrm{~mL}$ cold water and extracted with $3 * 10 \mathrm{~mL}$ ethyl acetate. The organic phases were combined, dried with anhydrous sodium sulfate, concentrated under reduced pressure, and separated by column chromatography (Petroleum ether: Ethyl acetate $=20: 3$ ) and a yellow solid was obtained. The yield was about $70 \%,{ }^{1} \mathrm{H}$ NMR (400 MHz, $\left.\mathrm{CDCl}_{3}\right): \delta 8.33(\mathrm{dd}, J=$ 8, 1.2 Hz, 1H), $8.06(\mathrm{~d}, J=8.0 \mathrm{~Hz}, 1 \mathrm{H}), 7.91(\mathrm{~d}, J=8.0 \mathrm{~Hz}, 1 \mathrm{H}), 7.69(\mathrm{~d}, J=7.6 \mathrm{~Hz}$, 
2H), 7.49-7.45 (m, 1H), $7.37(\mathrm{q}, J=15.2 \mathrm{~Hz}, 1 \mathrm{H}), 7.33-7.19(\mathrm{~m}, 1 \mathrm{H}), 7.20(\mathrm{t}, J=14.8$ $\mathrm{Hz}, 1 \mathrm{H}), 7.15$ (d, $J=7.6 \mathrm{~Hz}, 2 \mathrm{H}), 6.97$ (d, $J=8 \mathrm{~Hz}, 1 \mathrm{H}), 4.16$ (s, 2H), 3.53 (t, $J=12.8$ $\mathrm{Hz}, 2 \mathrm{H}), 2.94$ (q, J=14.8 Hz, 2H), 1.60-1.50 (m, 2H), 1.48-1.41 (m. 2H), 1.32 (s, 12H), 1.28-1.25 (m, 2H), $1.22(\mathrm{~s}, 1 \mathrm{H}) .{ }^{13} \mathrm{C} \mathrm{NMR}\left(100 \mathrm{MHz}, \mathrm{CDCl}_{3}\right): \delta 165.3,152.1,149.3$, $139.5,136.6,134.6,130.5,129.3,125.9,125.0,124.3,124.0,123.0,121.5,83.9,62.8$, 59.6, 52.8, 34.8, 32.5, 26.0, 25.4, 25.0, 23.6. HRMS m/z calcd for $\mathrm{C}_{31} \mathrm{H}_{37} \mathrm{BN}_{2} \mathrm{O}_{3} \mathrm{~S}[\mathrm{M}$ $+\mathrm{Na}]^{+}$551.2510, found 551.2493.

\section{Synthesis of Probe PTZ-H.}

A mixture of compound ONOO-B (40 mg, $0.075 \mathrm{mmol}$ ), compound S5 (37 mg, 0.15 mmol), EDCI (30 mg, $0.15 \mathrm{mmol}$ ) and DMAP (12 mg, $0.1 \mathrm{mmol}$ ) was dissolved in 10 $\mathrm{mL}$ 1,2-dichloroethane. The mixture was stirred at room temperature and monitored by TLC (petroleum ether: ethyl acetate $=3: 1$ ). Four hours later, the starting material was totally consumed as indicated by TLC. After the reaction was completed, the reaction solution was poured into $20 \mathrm{~mL}$ cold water, extracted three times with $60 \mathrm{~mL}$ ethyl acetate. The organic phases were dried with anhydrous sodium sulfate, evaporated under reduced pressure, and separated by column chromatography ( Petroleum ether: ethyl acetate $=3: 1)$ to obtain a red solid with a yield of about $80 \%,{ }^{1} \mathrm{H}$ NMR (400 $\left.\mathrm{MHz} \mathrm{CDCl}_{3}\right): \delta 8.34(\mathrm{~d}, J=7.6 \mathrm{~Hz}, 1 \mathrm{H}), 8.23(\mathrm{~s}, 1 \mathrm{H}), 8.00(\mathrm{~d}, J=8.4 \mathrm{~Hz}, 1 \mathrm{H}), 7.67$ $(\mathrm{d}, \mathrm{J}=7.6 \mathrm{~Hz}, 2 \mathrm{H}), 7.42(\mathrm{t}, \mathrm{J}=14.8 \mathrm{~Hz}, 1 \mathrm{H}), 7.36-7.27(\mathrm{~m}, 2 \mathrm{H}), 7.23-7.14(\mathrm{~m}, 2 \mathrm{H})$, 7.13-7.08 (m, 4H), $6.98(\mathrm{t}, J=14.8 \mathrm{~Hz}, 2 \mathrm{H}), 6.90(\mathrm{~d}, J=7.6 \mathrm{~Hz}, 1 \mathrm{H}), 6.63(\mathrm{~s}, 1 \mathrm{H}), 4.23$ (t, $J=12.8 \mathrm{~Hz}, 2 \mathrm{H}), 4.16(\mathrm{~s}, 2 \mathrm{H}), 3.85$ (t, $J=15.2 \mathrm{~Hz}, 2 \mathrm{H}), 2.99$ (s, 2H), 1.83-1.76 (m, $2 \mathrm{H}), 1.72-1.56(\mathrm{~m}, 4 \mathrm{H}), 1.49-1.37$ (m, 2H), 1.31 (s, 12H), 1.28-1.23 (m, 2H), 0.96 (t, $J$ $=6.4 \mathrm{~Hz}, 3 \mathrm{H}) .{ }^{13} \mathrm{C} \mathrm{NMR}\left(100 \mathrm{MHz}, \mathrm{CDCl}_{3}\right): \delta 165.1,163.4,157.2,156.6,152.0,151.0$, 147.8, 142.4, 134.5, 130.6, 129.3, 127.9, 127.6, 126.2, 125.9, 125.0, 124.0, 122.9, 121.4, 121.1, 116.2, 113.3, 112.8, 102.1, 83.9, 65.6, 52.6, 48.4, 28.5, 27.0, 26.1, 25.0, 22.7, 20.1, 13.8. HRMS m/z calcd for $\mathrm{C}_{51} \mathrm{H}_{52} \mathrm{BN}_{3} \mathrm{O}_{6} \mathrm{~S}_{2}[\mathrm{M}+\mathrm{Na}]^{+}, 900.3288$, found 900.3277. 


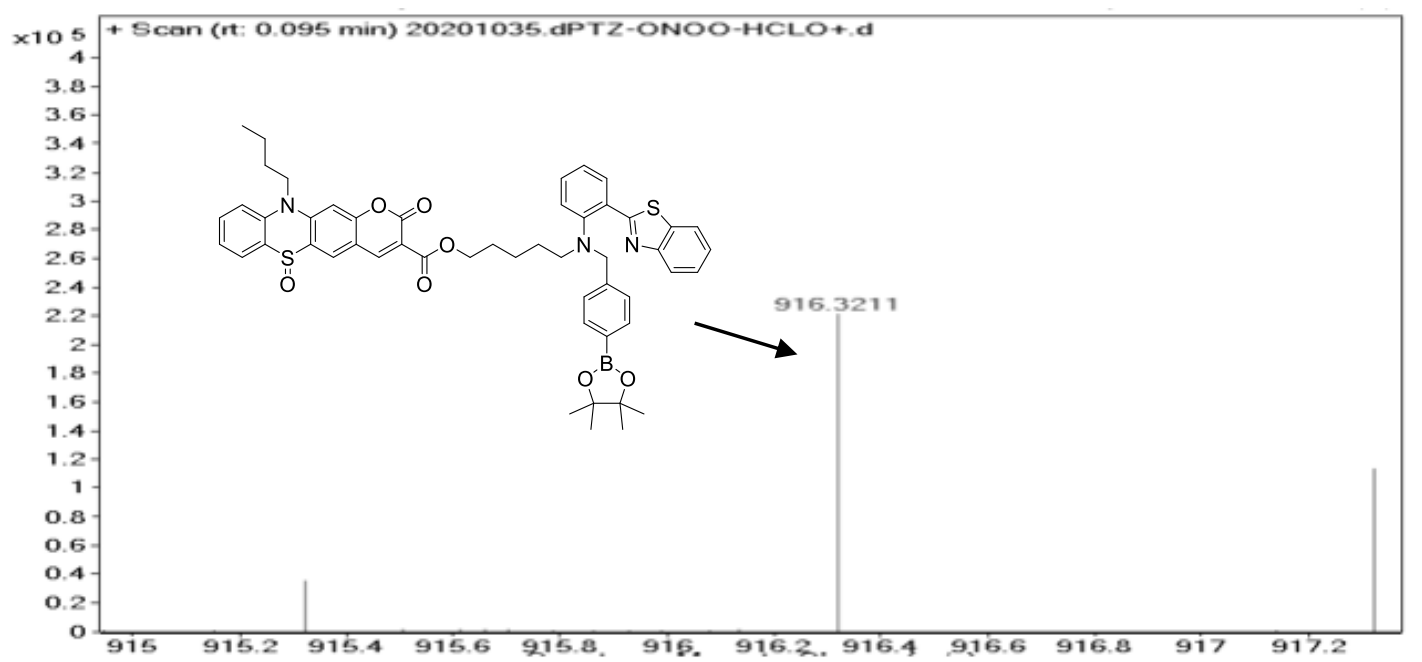

Figure S1. HRMS spectrum for the product (PTZ-H-ClO-) of PTZ-H with $\mathrm{ClO}^{-}$.

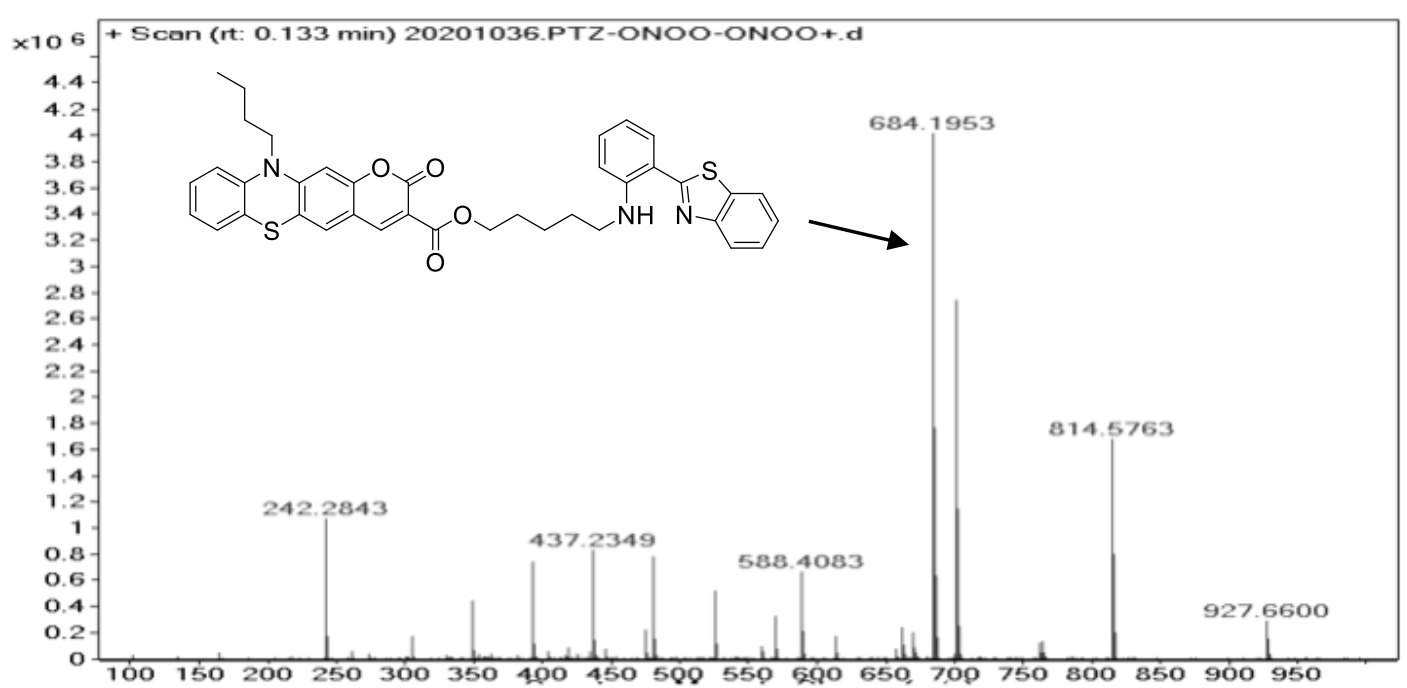

Figure S2. HRMS spectrum for the product (PTZ-H-ONOO-) of PTZ-H with ONOO-

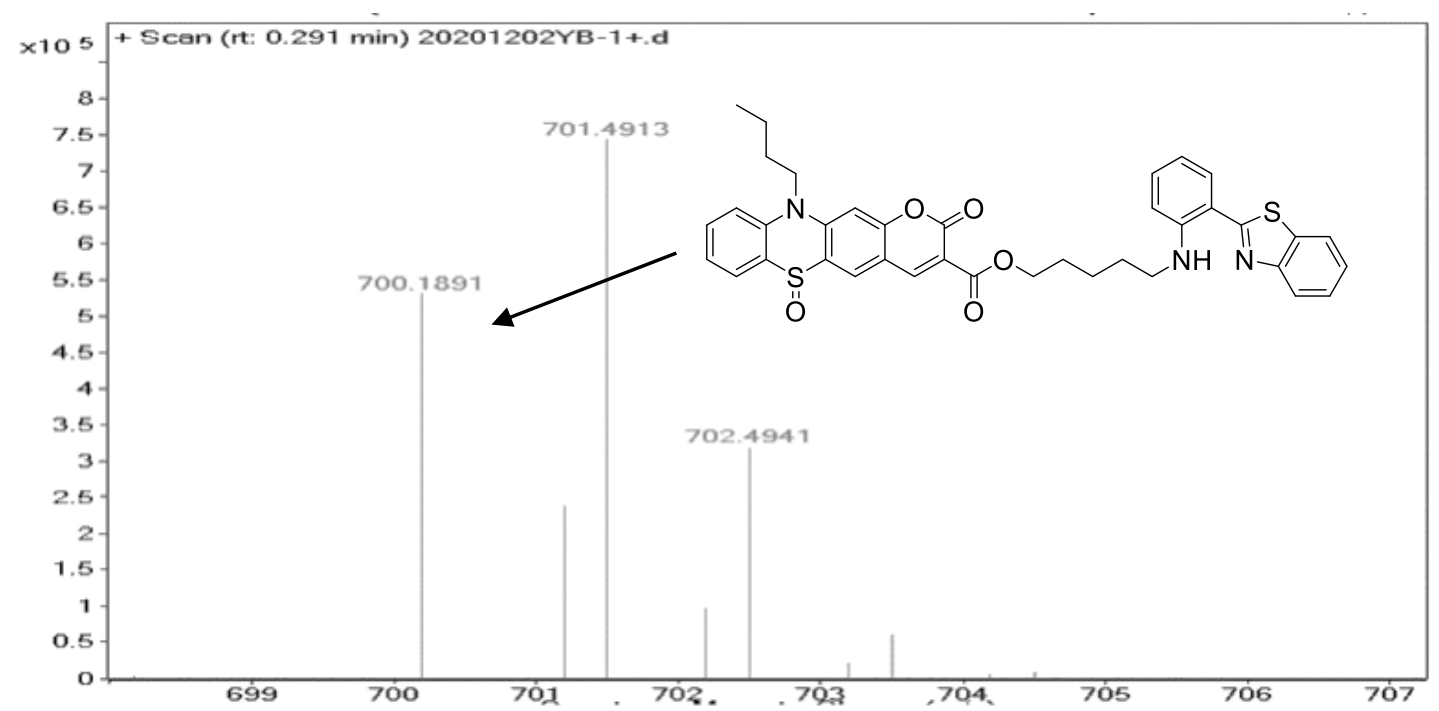

Figure S3. HRMS spectrum for the product (PTZ-H-ClO-\&ONOO-) of PTZ-H with 
$\mathrm{ClO}^{-}$and $\mathrm{ONOO}^{-}$.

(a)

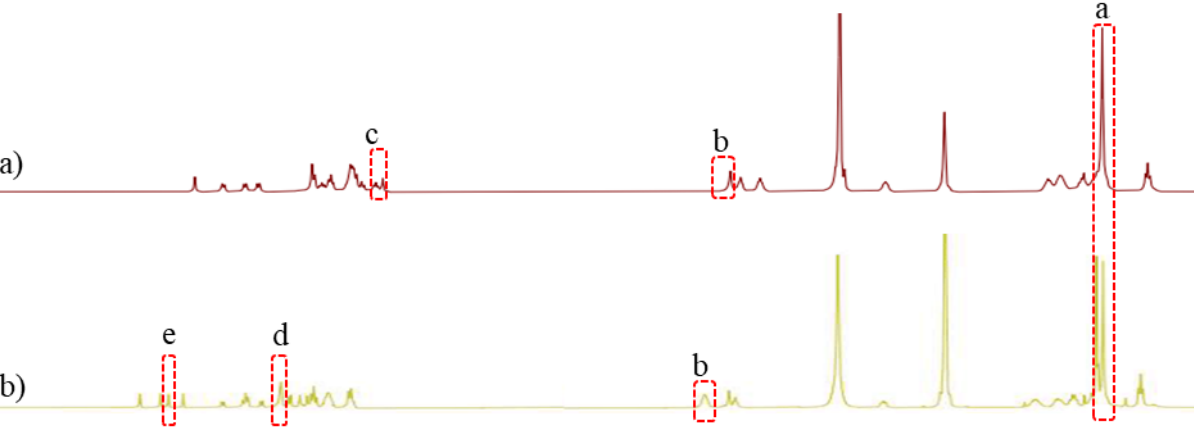

(c)
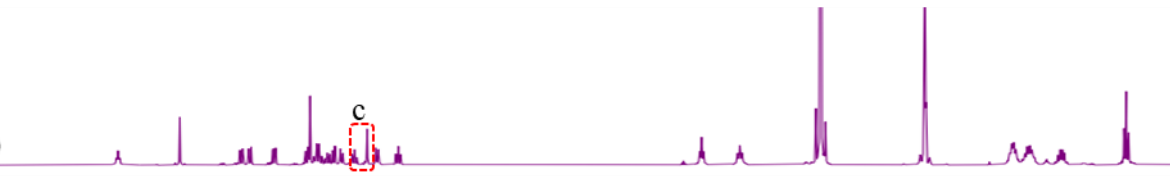

(d)

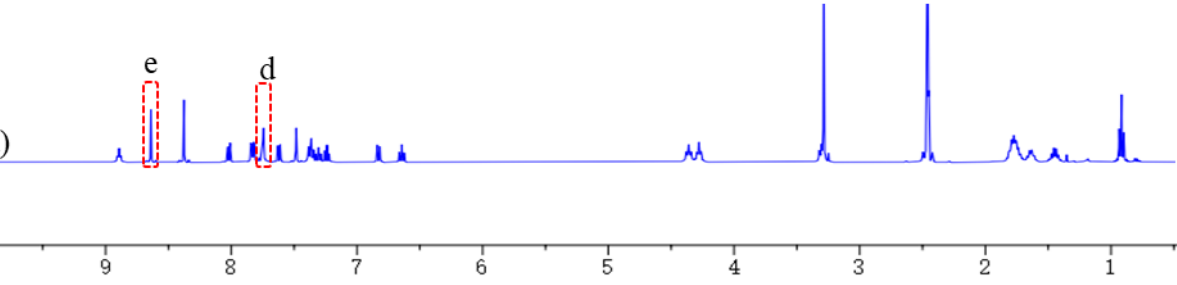

Figure S4. The ${ }^{1} \mathrm{H}$ NMR (400 MHz, DMSO-d6): comparison diagram of (a) PTZ-H; (b) $\mathrm{PTZ}-\mathrm{H}$ reacted with $\mathrm{ClO}^{-}$; (c) $\mathrm{PTZ}-\mathrm{H}$ reacted with $\mathrm{ONOO}^{-}$; (d) $\mathrm{PTZ}-\mathrm{H}$ reacted with $\mathrm{ONOO}^{-}$and $\mathrm{ClO}^{-}$. (a: peaks of methyl hydrogen on benzylphenylborate; b: peaks of methylene hydrogen on benzylphenylborate; c: peaks of two hydrogens on the benzene nearest to the sulfur atom; $d$ and e: peaks of two aromatic hydrogens adjacent to the sulfoxide group).
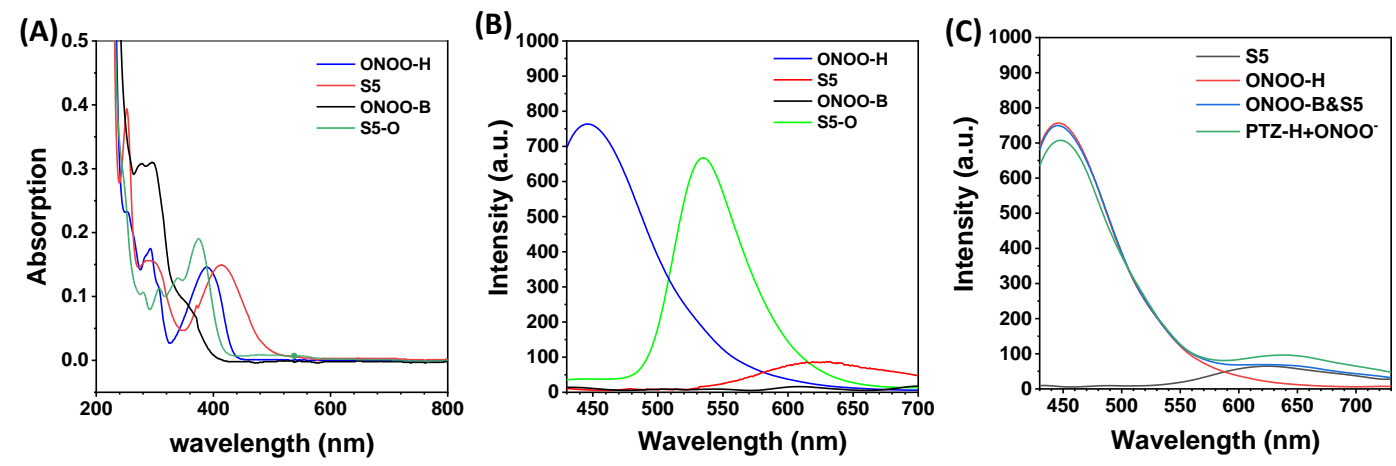

Figure S5. (A) Absorption spectra for ONOO-H (2-(benzo[d]thiazol-2-yl)aniline fragment); S5 (fused phenothiazine-based coumarin); ONOO-B [2-(benzo[d]thiazol-2yl)-N-(4-(4,4,5,5-tetramethyl-1,3,2-dioxaborolan-2-yl)benzyl)aniline fragment]; S5-O 
(sulfoxide phenothiazine-based coumarin). (B) Emission spectra for ONOO-H (2(benzo[d]thiazol-2-yl)aniline fragment); $\mathbf{S 5}$ (fused phenothiazine-based coumarin, $\lambda_{\mathrm{ex}}$ $=400 \mathrm{~nm}) ;$ ONOO-B $\quad[2-($ benzo[d]thiazol-2-yl)-N-(4-(4,4,5,5-tetramethyl-1,3,2dioxaborolan-2-yl)benzyl)aniline fragment]; S5-O (sulfoxide phenothiazine-based coumarin), $\lambda_{\mathrm{ex}}=400 \mathrm{~nm}$. (C) Emission spectra for $\mathbf{S 5}$ (fused phenothiazine-based coumarin, $\lambda_{\mathrm{ex}}=400 \mathrm{~nm}$ ); ONOO-H (2-(benzo[d]thiazol-2-yl)aniline fragment, $\lambda_{\mathrm{ex}}=$ $400 \mathrm{~nm}) ;$ ONOO-B (2-(benzo[d]thiazol-2-yl)aniline fragment) and S5 [2(benzo[ $d]$ thiazol-2-yl)-N-(4-(4,4,5,5-tetramethyl-1,3,2-dioxaborolan-2-yl)benzyl)-

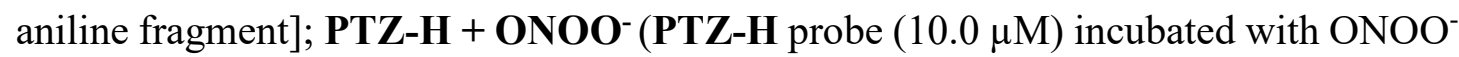
$(40.0 \mu \mathrm{M}) . \lambda_{\mathrm{ex}}=400 \mathrm{~nm}$.

(A)

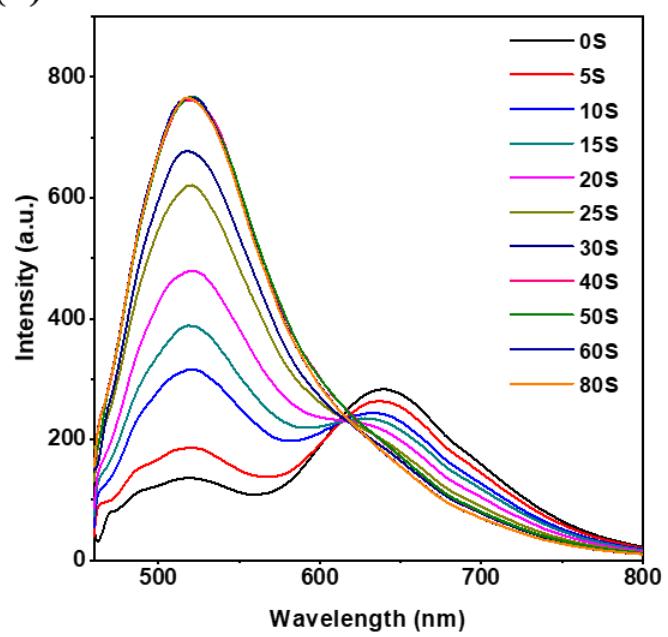

(B)

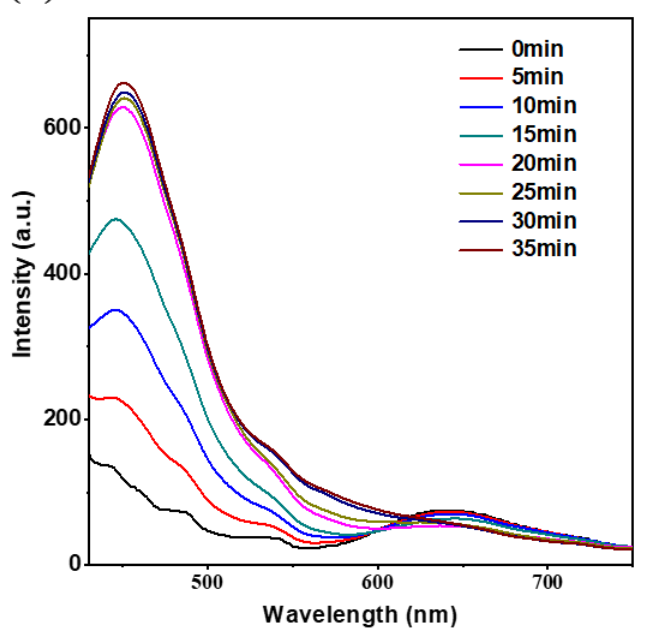

Figure S6. (A) Fluorescence spectra of probe PTZ-H $(10 \mu \mathrm{M})$ and $\mathrm{ClO}^{-}(40 \mu \mathrm{M})$ incubated at $37^{\circ} \mathrm{C}$ for $0,5,10,15,20,25,30,40,50,60,80$ s. (B) Fluorescence spectra of probes PTZ-H $(10 \mu \mathrm{M})$ and $\mathrm{ONOO}^{-}(40 \mu \mathrm{M})$ incubated at $37^{\circ} \mathrm{C}$ for $0,5,10,15,20$, $25,30,35 \mathrm{~min}$ 


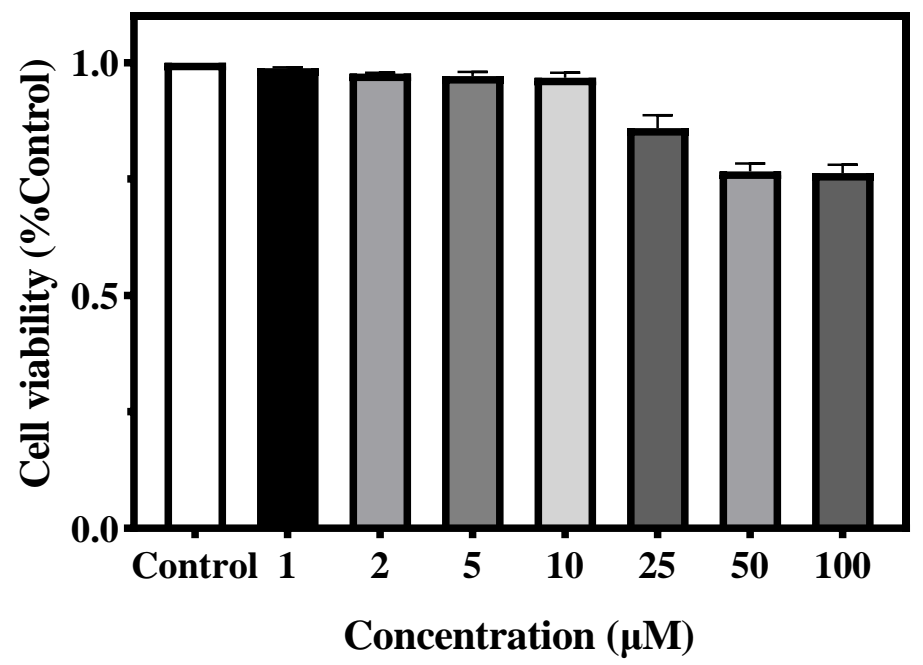

Figure S7. Cytotoxicity of PTZ-H at various concentrations $(1 \mu \mathrm{M}, 2 \mu \mathrm{M}, 5 \mu \mathrm{M}, 10$ $\mu \mathrm{M}, 25 \mu \mathrm{M}, 50 \mu \mathrm{M}$ and $100 \mu \mathrm{M})$ in living RAW 264.7 cells for $24 \mathrm{~h}$.

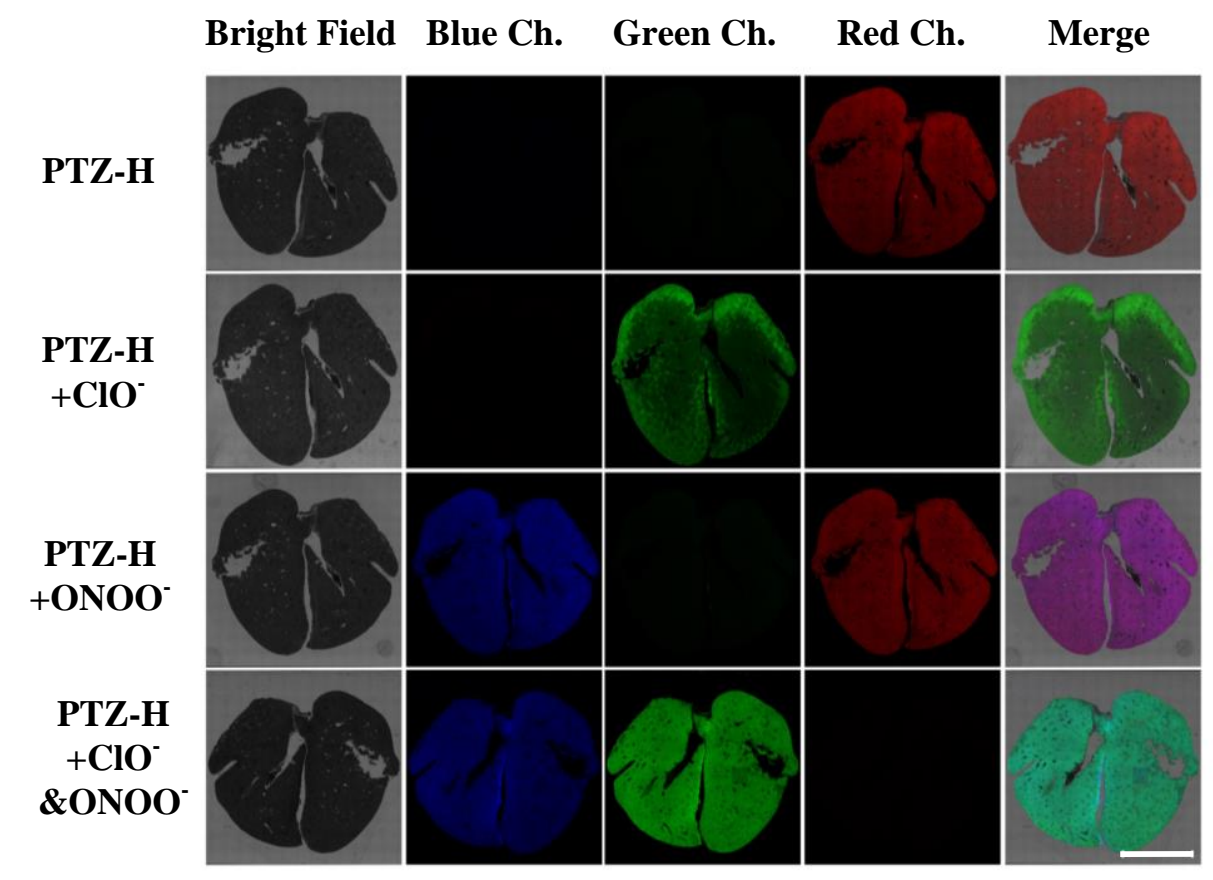

Figure S8. Confocal fluorescence images of liver slices. PTZ-H group: Liver Slices were incubated with the PTZ-H probe $(5.0 \mu \mathrm{M})$. PTZ-H $+\mathbf{C l O}^{-}$group: The liver slices were pretreated with $\mathrm{ClO}^{-}(50.0 \mu \mathrm{M})$ and then incubated with PTZ-H probe $(5.0 \mu \mathrm{M})$. PTZ-H+ONOO- ${ }^{-}$group: The liver slices were pretreated with $\mathrm{ONOO}^{-}(50 \mu \mathrm{M})$ and then incubated with PTZ-H probe $(5.0 \mu \mathrm{M})$. PTZ-H+ClO ${ }^{-} \mathbf{\&} \mathbf{O N O O}^{-}$group: The liver slices were pretreated with $\mathrm{ClO}^{-}(50 \mu \mathrm{M})$ and $\mathrm{ONOO}^{-}(50.0 \mu \mathrm{M})$, subsequently incubated with PTZ-H probe $(5.0 \mu \mathrm{M})$. Scale bar, $50.0 \mathrm{~mm}$. 


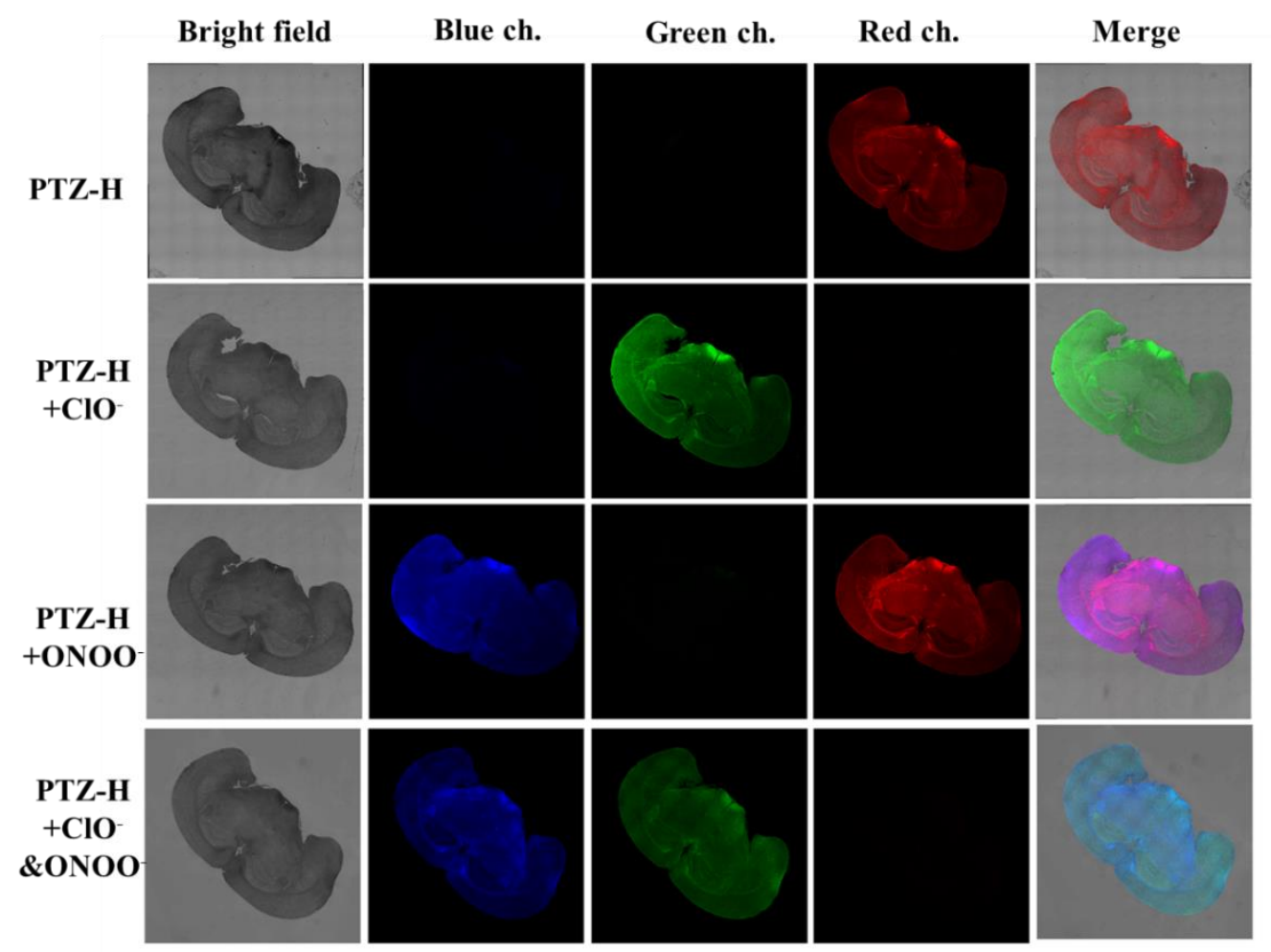

Figure S9. Confocal fluorescence images of hippocampal brain slices. (A) Hippocampal brain slices were incubated with the PTZ-H probe $(5 \mu \mathrm{M})$ for $20 \mathrm{~min}$. (B) The PTZ-H-pretreated hippocampal brain slices were incubated with $\mathrm{ClO}^{-}(50 \mu \mathrm{M})$ for 20 min. (C) The PTZ-H-pretreated hippocampal brain slices were incubated with ONOO$^{-}(50 \mu \mathrm{M})$ for $20 \mathrm{~min}$. (D) The PTZ-H-pretreated hippocampal brain slices were incubated with $\mathrm{ClO}^{-}$for $20 \mathrm{~min}$, and then $\mathrm{ONOO}^{-}$for a period of $30 \mathrm{~min}$. (E) The PTZH-pretreated hippocampal brain slices were incubated with $\mathrm{ONOO}^{-}$for $20 \mathrm{~min}$, and then $\mathrm{ClO}^{-}$for $20 \mathrm{~min}$. 


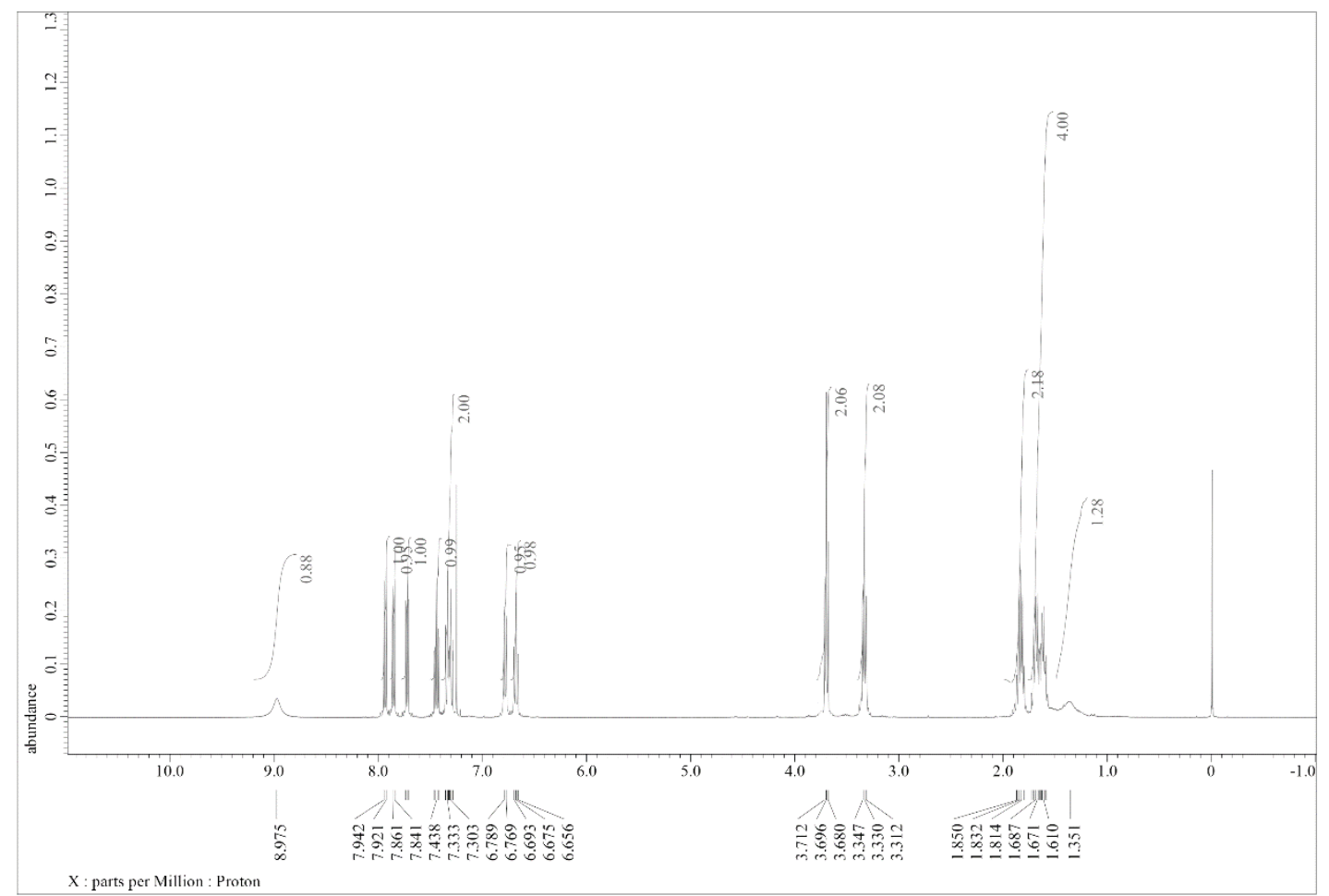

Figure S10. ${ }^{1} \mathrm{H}-\mathrm{NMR}\left(\mathrm{CDCl}_{3}\right)$ spectrum of compound $\mathbf{O N O O - O H}$

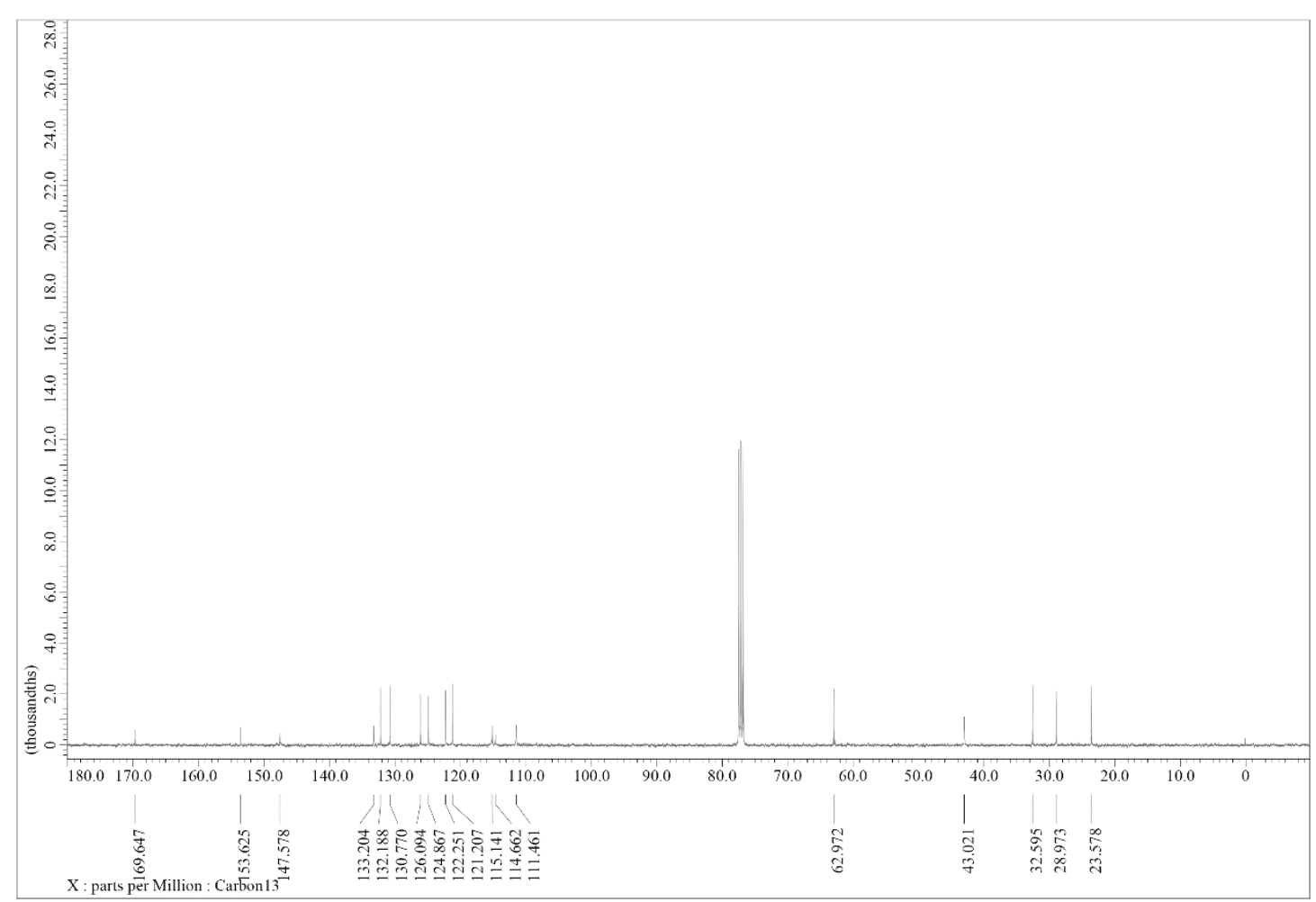

Figure S11. ${ }^{13} \mathrm{C}-\mathrm{NMR}\left(\mathrm{CDCl}_{3}\right)$ spectrum of compound $\mathbf{O N O O - O H}$ 


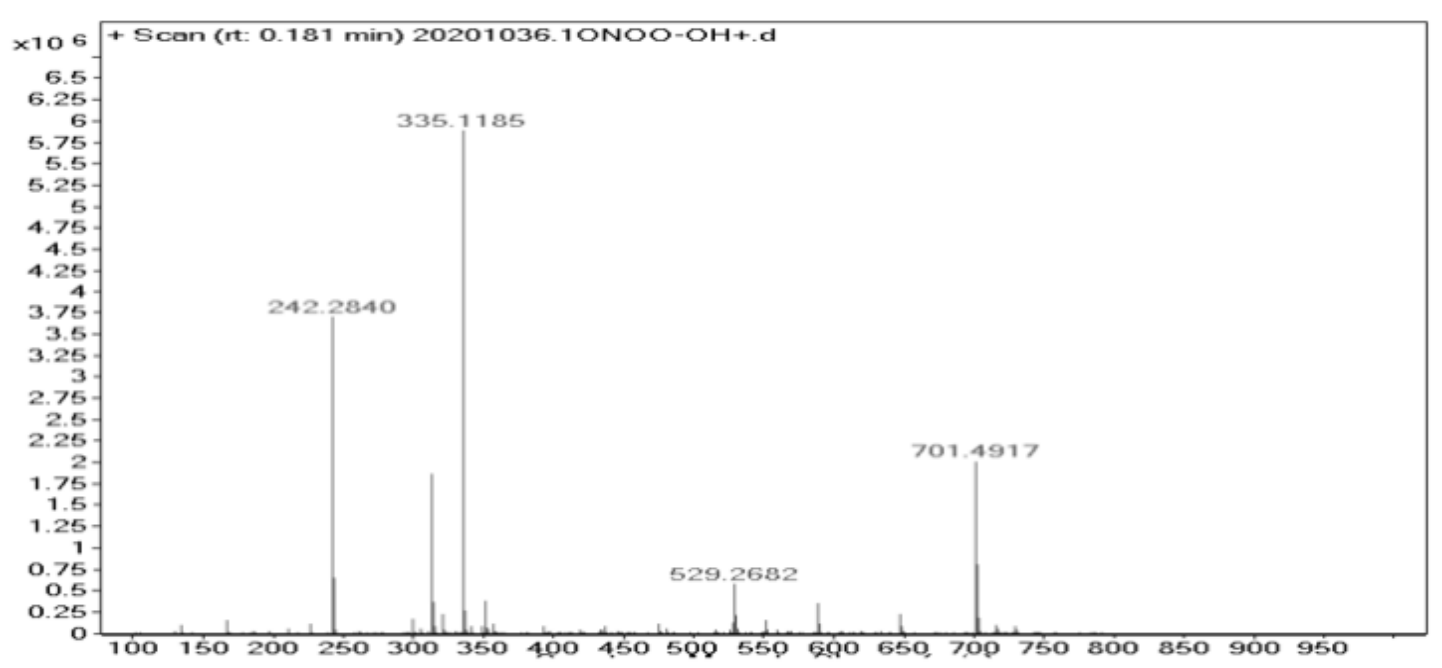

Figure S12. HRMS spectrum of compound ONOO-OH

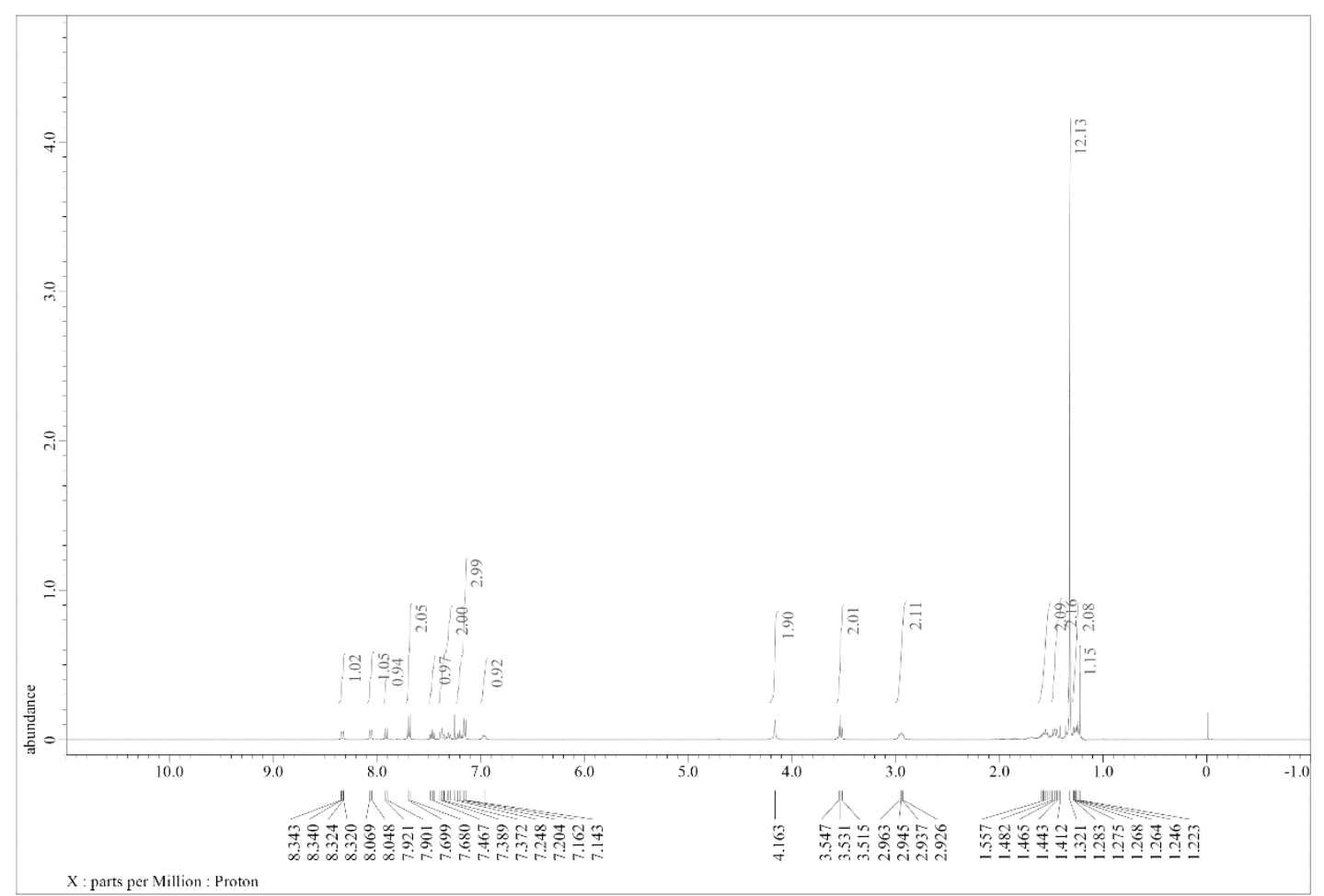

Figure S13. ${ }^{1} \mathrm{H}-\mathrm{NMR}\left(\mathrm{CDCl}_{3}\right)$ spectrum of compound ONOO-B 


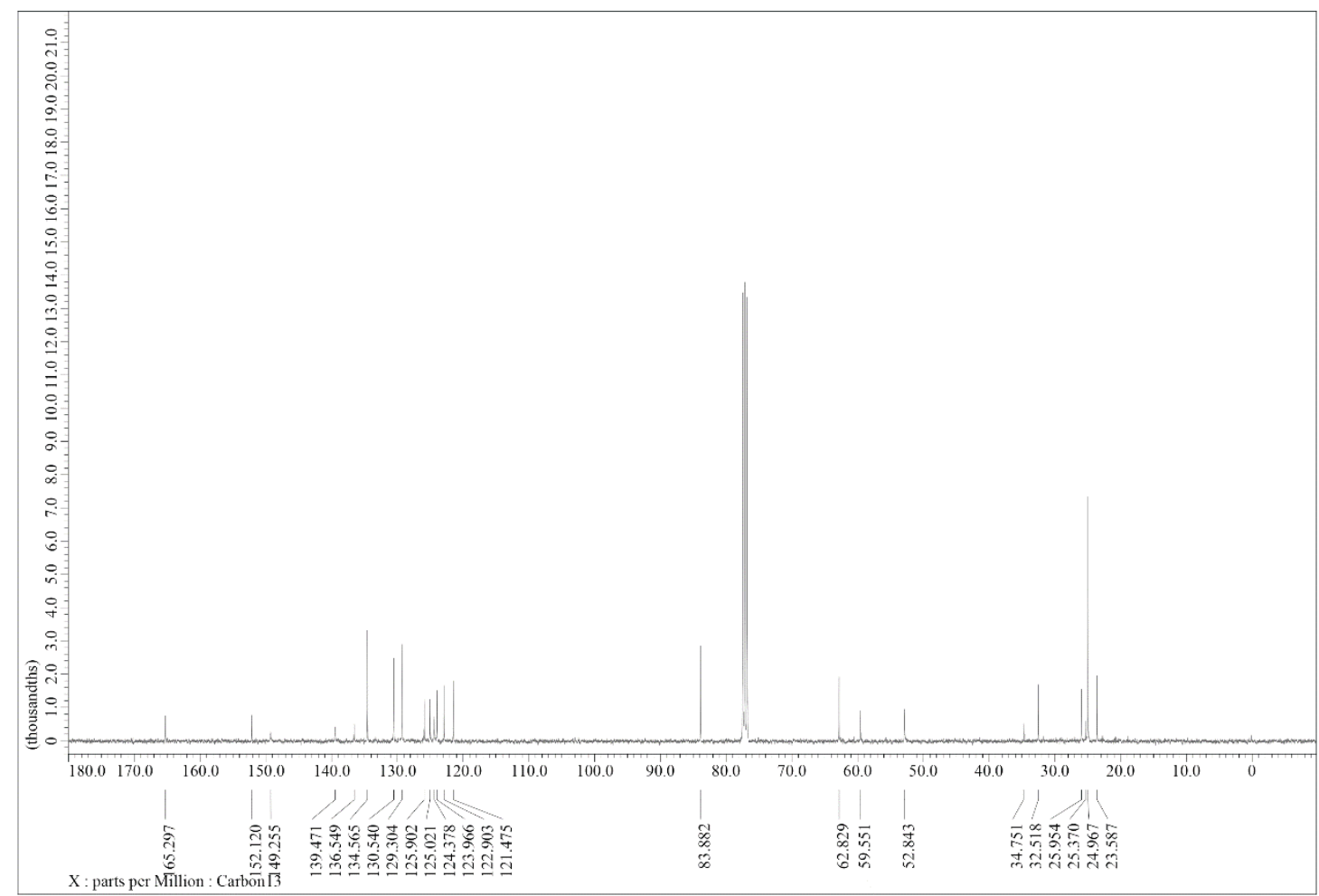

Figure S14. ${ }^{13} \mathrm{C}-\mathrm{NMR}\left(\mathrm{CDCl}_{3}\right)$ spectrum of compound ONOO-B

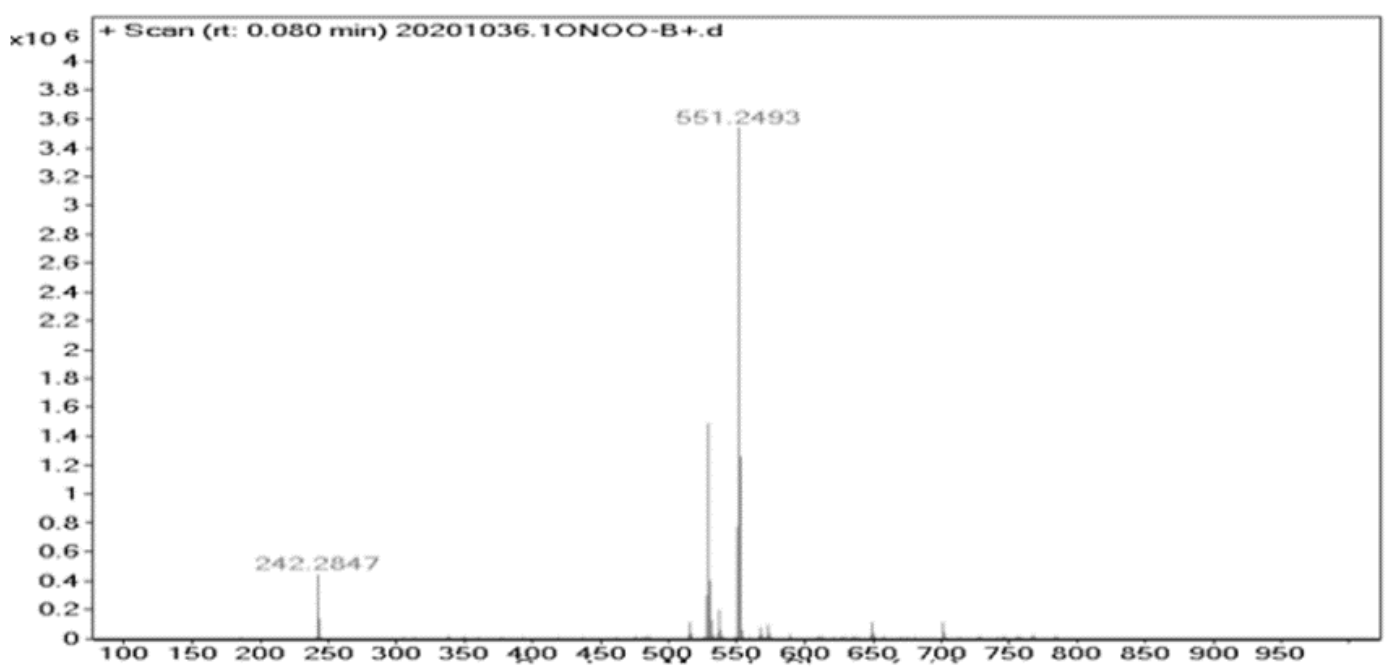

Figure S15. HRMS spectrum of compound ONOO-B 


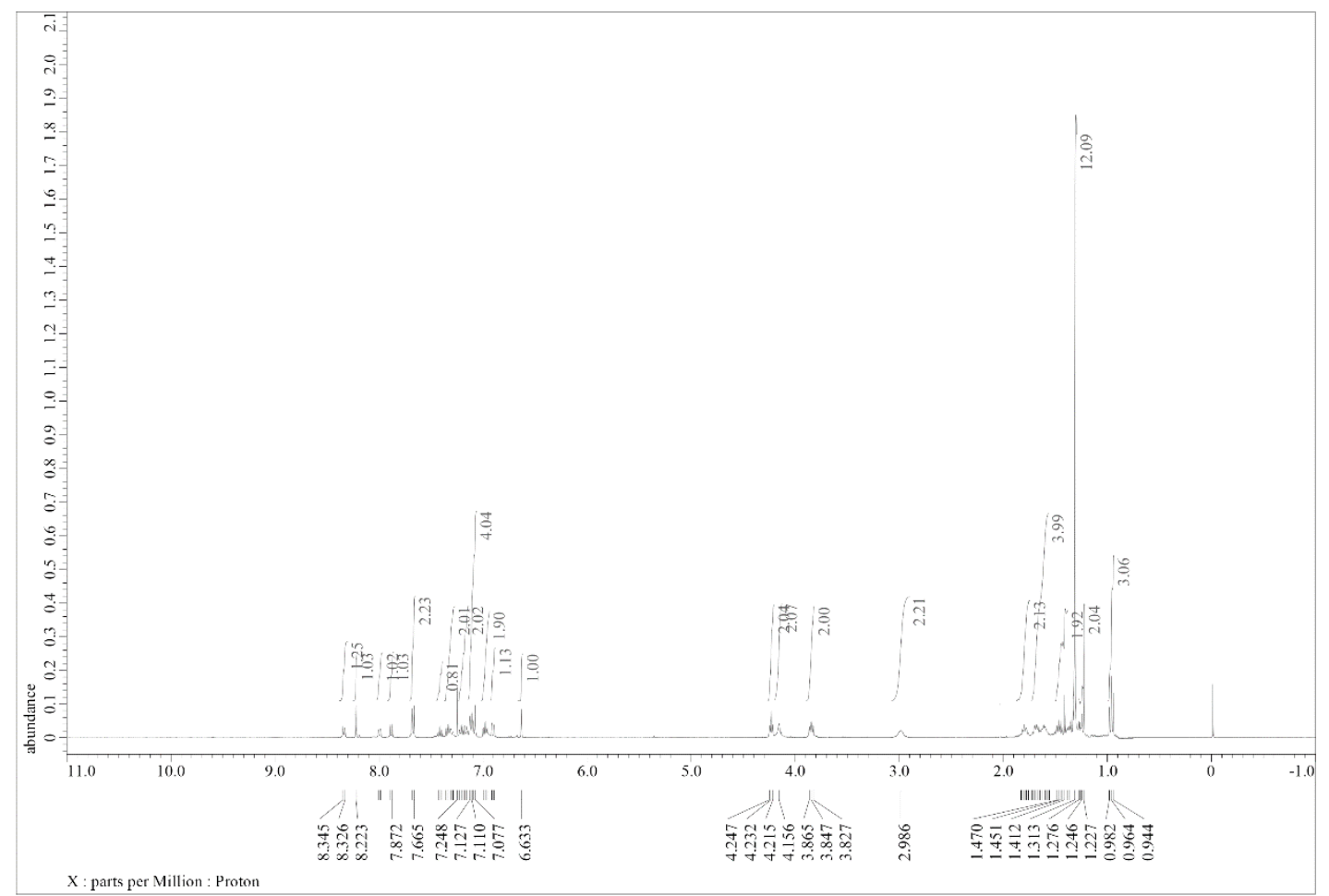

Figure S16. ${ }^{1} \mathrm{H}-\mathrm{NMR}\left(\mathrm{CDCl}_{3}\right)$ spectrum of compound PTZ-H

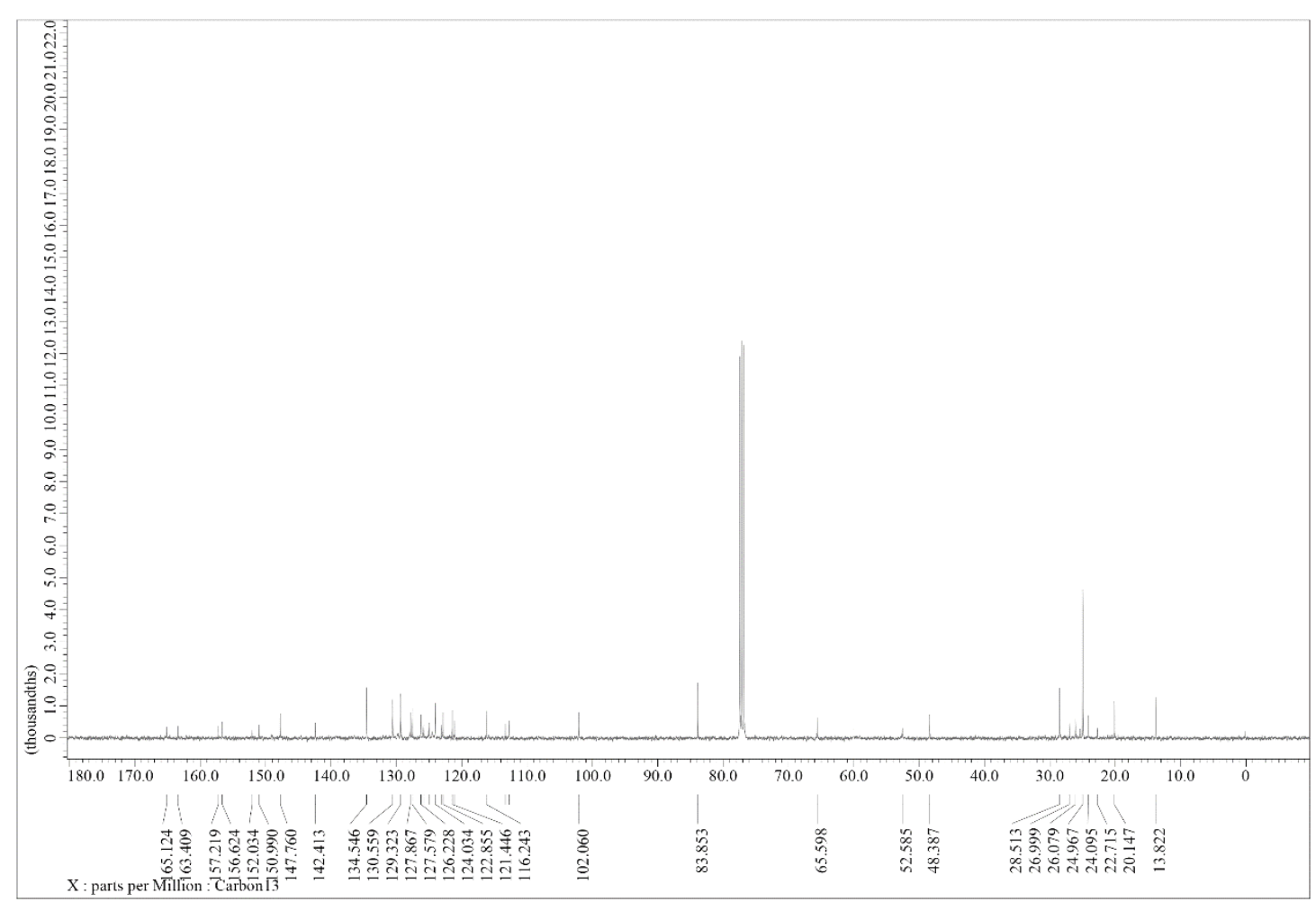

Figure S17. ${ }^{13} \mathrm{C}-\mathrm{NMR}\left(\mathrm{CDCl}_{3}\right)$ spectrum of compound PTZ-H 


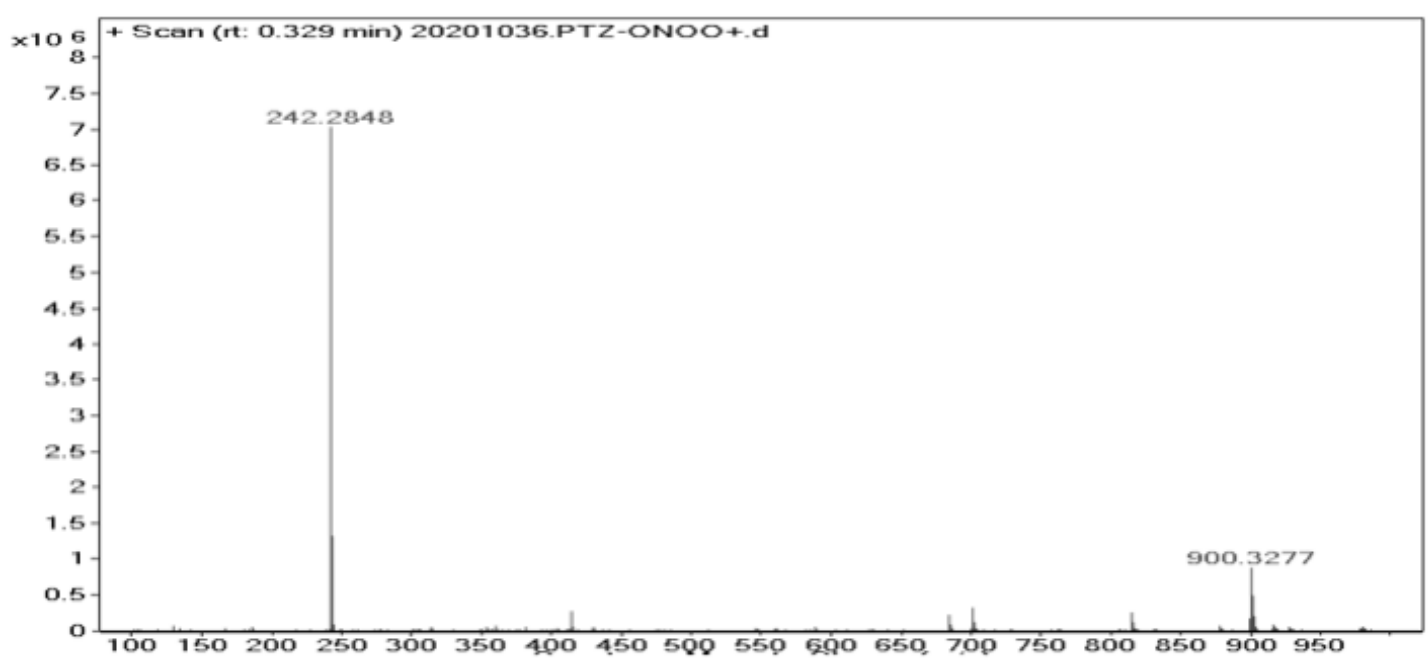

Figure S18. HRMS spectrum of compound PTZ-H

\section{REFERENCES}

[1] Sedgwick, A. C.; Sun, X.; Kim, G.; Yoon, J.; Bull, S. D.; James, T. D., Boronate based fluorescence (ESIPT) probe for peroxynitrite. Chem. Commun. 2016, 52(83), 12350-12352.

[2] Chen, W.; Li, G.; Chen, C.; Sheng, J.; Yang, L., Aggregation-enhanced emission enables phenothiazine coumarin as a robust ratiometric fluorescent for rapid and selective detection of HClO. Spectrochim Acta A Mol Biomol Spectrosc 2020, 228, 117724. 